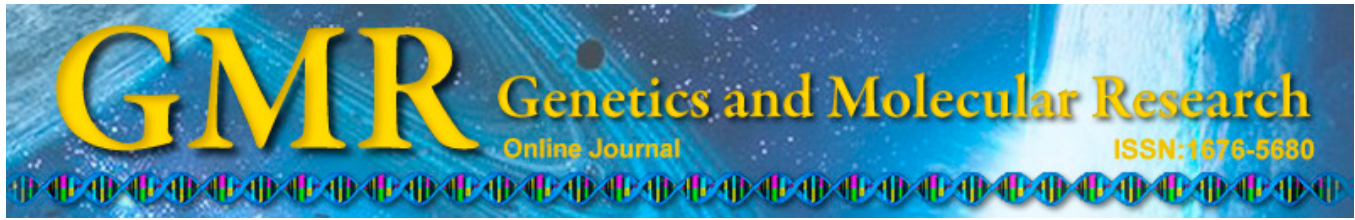

\title{
Morphological and molecular characterization of Fusarium spp pathogenic to pecan tree in Brazil
}

\author{
M. Lazarotto ${ }^{1}$, P.M. Milanesi ${ }^{2}$, M.F.B. Muniz ${ }^{2}$, L.R.S. Reiniger ${ }^{3}$, \\ R. Beltrame ${ }^{4}$, R. Harakava ${ }^{5}$ and E. Blume ${ }^{2}$ \\ ${ }^{1}$ Departamento de Horticultura e Silvicultura, \\ Universidade Federal do Rio Grande do Sul, Porto Alegre, RS, Brasil \\ ${ }^{2}$ Departmento de Defesa Fitossanitária, Universidade Federal de Santa Maria, \\ Santa Maria, RS, Brasil \\ ${ }^{3}$ Departmento de Fitotecnia, Universidade Federal de Santa Maria, \\ Santa Maria, RS, Brasil \\ ${ }^{4}$ Engenharia Industrial Madeireira, Universidade Federal de Pelotas, Pelotas, \\ RS, Brasil \\ ${ }^{5}$ Instituto Biológico de São Paulo, São Paulo, SP, Brasil
}

Corresponding author: M. Lazarotto

E-mail: lilalazarotto@yahoo.com.br

Genet. Mol. Res. 13 (4): 9390-9402 (2014)

Received March 12, 2014

Accepted June 26, 2014

Published November 11, 2014

DOI http://dx.doi.org/10.4238/2014.November.11.5

\begin{abstract}
The occurrence of Fusarium spp associated with pecan tree (Carya illinoinensis) diseases in Brazil has been observed in recent laboratory analyses in Rio Grande do Sul State. Thus, in this study, we i) obtained Fusarium isolates from plants with disease symptoms; ii) tested the pathogenicity of these Fusarium isolates to pecan; iii) characterized and grouped Fusarium isolates that were pathogenic to the pecan tree based on morphological characteristics; iv) identified Fusarium spp to the species complex level through TEF$1 \alpha$ sequencing; and v) compared the identification methods used in the study. Fifteen isolates collected from the inflorescences, roots, and
\end{abstract}


seeds of symptomatic plants (leaf necrosis or root rot) were used for pathogenicity tests. Morphological characterization was conducted using only pathogenic isolates, for a total of 11 isolates, based on the mycelial growth rate, sporulation, colony pigmentation, and conidial length and width variables. Pathogenic isolates were grouped based on morphological characteristics, and molecular characterization was performed by sequencing $T E F-1 \alpha$ genes. Pathogenic isolates belonging to the Fusarium chlamydosporum species complex, Fusarium graminearum species complex, Fusarium proliferatum, and Fusarium oxysporum were identified based on the TEF-1 $\alpha$ region. Morphological characteristics were used to effectively differentiate isolates and group the isolates according to genetic similarity, particularly conidial width, which emerged as a key morphological descriptor in this study.

Key words: Pathogenicity; Morphological characters; TEF-1 $\alpha$; Unweighted pair group method with arithmetic mean

\section{INTRODUCTION}

The pecan tree [Carya illinoinensis (Wangenh.) K. Koch] belongs to the botanical family Juglandaceae and includes the genera Carya and Juglans, which are best known in Southern Brazil for their production of edible nuts and valuable timber (Marchiori, 1997). In Southern Brazil, the area dedicated to pecan production has increased, particularly because this species produces nuts between 5 and 6 years of age. This growth has been accompanied by an increased incidence of diseases caused by fungi, bacteria, or other microorganisms, which are not well understood. Therefore, many of the pathogens causing disease in pecan trees in Brazil have not been identified and reported.

Some fungi, such as those causing scab disease (Cladosporium caryigenum), which is the main disease that attacks young tissues, anthracnose (Colletotrichum gloesporioides), which causes depressed lesions in fruits, mold (Cephalothecium roseum), powdery mildew (Microsphaera penicillata), phytophthora rot (Phytophthora cactorum), and leaf blight, whose etiology remains unclear, have been described by Ortiz and Camargo (2005).

A new type of rot root disease has been identified in Rio Grande do Sul State of Brazil, which is associated to Fusarium genus fungi. This disease particularly attacks seedlings in the nursery by causing wilt and foliar necrosis associated with root rot, but also occurs in the field where plants exhibit reduced development. The intensity of attack in the nursery is approximately $10 \%$; in severe cases, seedling death occurs.

According to Taylor et al. (2000), the most effective method for identifying fungi is based on the phylogenetic species concept via phylogenetic analysis of variable characteristics of nucleic acids. However, Leslie and Summerell (2006) reported that although DNA sequences are the most frequently used characteristics for identifying and delimiting phylogenetic species, other sufficiently informative markers, including morphological characteristics, can be used to delineate phylogenetic species.

The region most commonly used for the molecular identification of fungi is the internal transcribed spacer (ITS) in the ribosomal RNA gene structure, which is divided into the $18 \mathrm{~S}, 5.8 \mathrm{~S}$, and $28 \mathrm{~S}$ regions, in addition to ITS1 and ITS2. Waalwijk et al. (1996) found 
sequencing the ITS region is effective for identifying some species of Fusarium, but that the presence of 2 non-homologous copies within the ITS2 region causes divergent results. The translation elongation factor $1 \alpha(T E F-1 \alpha)$ region is highly conserved, involved in translation processes, and has recently been widely examined in intra- and inter-specific variation studies and phylogenetic analyses of a wide variety of eukaryotic groups, including fungi from the Fusarium genus (O’Donnell et al., 1998).

The aims of this study were the following: i) obtain Fusarium isolates from plants with symptoms of disease; ii) test the pathogenicity of these Fusarium isolates to pecan; iii) characterize and group Fusarium isolates that are pathogenic to the pecan tree based on morphological characteristics; iv) identify Fusarium spp to the species complex level through $T E F-1 \alpha$ sequencing; and v) compare the identification methods used in the study.

\section{MATERIAL AND METHODS}

\section{Preparation and purification of Fusarium spp isolates}

Symptomatic samples were collected from pecan orchards in different municipalities of the State of Rio Grande do Sul (RS), Brazil. The intensity of attack of the disease was approximately $10 \%$ in the nursery. All collection points were georeferenced using a global positioning system as shown in Table 1.

Table 1. Coordinates of the collection locations of Fusarium spp isolates derived from pecan tree orchards in RS.

\begin{tabular}{lllr}
\hline Municipality & Date & Coordinates (DMS) & Altitude (m) \\
\hline Cachoeira do Sul & November 2010 & $29^{\circ} 59^{\prime} 45^{\prime \prime} \mathrm{S}-52^{\circ} 55^{\prime} 22^{\prime \prime} \mathrm{W}$ & 114 \\
Mata & December 2010 & $29^{\circ} 31^{\prime} 3$ "S-48 $27^{\prime} 39^{\prime \prime} \mathrm{W}$ & 208 \\
Anta Gorda & January 2011 & $28^{\circ} 53^{\prime} 54.7^{\prime \prime} \mathrm{S}-52^{\circ} 01^{\prime} 59.9^{\prime \prime} \mathrm{W}$ & 514 \\
Santa Maria & November 2010 & $29^{\circ} 43^{\prime} 13.0^{\prime \prime} \mathrm{S}-53^{\circ} 43^{\prime} 1.9^{\prime \prime} \mathrm{W}$ & 88 \\
\hline
\end{tabular}

$\overline{\mathrm{DMS}}=$ degrees minutes and seconds coordinates.

Isolates were collected from municipalities in the State of Rio Grande do Sul, Brazil from October 2010 to August 2011 and were derived from different plant components presenting symptoms such as leaf necrosis, shoot wilt, and root rot. $\mathrm{F}_{1}, \mathrm{~F}_{6}, \mathrm{~F}_{7}, \mathrm{~F}_{8}$, and $\mathrm{F}_{15}$ were isolated from inflorescences in the municipality of Santa Maria; $\mathrm{F}_{3}$ and $\mathrm{F}_{14}$ were isolated from inflorescences in the municipality of Anta Gorda; $\mathrm{F}_{5}$ was obtained from roots in the municipality of Cachoeira do Sul; $F_{9}$ and $F_{11}$ were isolated from roots in Mata; $F_{17}$ was obtained from roots in Santa Maria; and $\mathrm{F}_{19}, \mathrm{~F}_{20}, \mathrm{~F}_{21}$, and $\mathrm{F}_{23}$ were isolated from seeds in the municipality of Anta Gorda. All samples were collected and stored in paper bags until being taken to the laboratory for pathogen analysis and identification.

Plant materials (inflorescences, roots, and seeds) collected in the field were placed in a humid chamber for 3 days for subsequent identification. After pathogen detection, plant tissues were surface-sterilized and the pathogen structures were transferred to Petri dishes containing potato dextrose agar (PDA) culture media using a histology needle as described by Alfenas and Maffia (2007). After 10 days of growth, the cultured isolates were purified by single-conidial purification and stored on Synthetischer Nährstoffarmer agar (SNA) culture media for subsequent use. 


\section{Pathogenicity test}

The following procedures were performed for all the isolates collected, for a total of 15 isolates. a) Inoculation of Fusarium spp in maize kernels: maize kernels were soaked in water and incubated at room temperature for $8 \mathrm{~h}$, after which excess water was discarded and approximately $80 \mathrm{~g}$ kernels were placed in $100-\mathrm{mL}$ glass flasks to be autoclaved twice for $40 \mathrm{~min}$ at an interval of $24 \mathrm{~h}$. After cooling, 5 5-mm-diameter PDA culture medium discs containing pathogen mycelia were transferred to each vial. The flasks were incubated at $24^{\circ} \mathrm{C}$ for 14 days with 12-h light/dark cycles according to a method adapted from Klingelfuss et al. (2007). Five PDA culture medium discs not containing pathogens were used as controls. b) Inoculation: plastic trays (approximate capacity $7 \mathrm{~L}$ ) with holes in the bottom were filled approximately halfway with commercial substrate (composition: Sphagnum peat, expanded vermiculite, dolomitic limestone, agricultural gypsum, and NPK fertilizer; $101 \mathrm{~kg} / \mathrm{m}^{3}$ density). Next, $80 \mathrm{~cm}^{3}$ inoculated maize kernels was mixed with the substrate, which was then moistened with sterile distilled water. Subsequently, 20 seeds derived from pecan tree seedlings produced by seeds (without cultivar identification), divided into 4 sets of replicates, were sown in each treatment substrate. The seeds were manually sanded at the opposite end from the embryo to overcome dormancy. The trays were maintained in a temperature-controlled room at $25^{\circ} \mathrm{C} \pm 2{ }^{\circ} \mathrm{C}$ with a 12-h photoperiod for 90 days, after which the percentage of disease incidence (presence of symptoms like leaf necrosis, choke disease, root rot) was assessed for each isolate, with subsequent pathogen re-isolation on PDA and carnation leaf agar (CLA) media toward fulfilling Koch's postulates. All isolates were replicated on Synthetischer Nährstoffarmer agar (SNA) media for storage. The next procedures were conducted using only the isolates that had been identified as pathogenic to pecan.

\section{Morphological characterization of pathogenic isolates}

Morphological characterization was done only with the 11 Fusarium spp isolates identified as being pathogenic to the pecan tree. The procedures were based on the method described by Michereff et al. (2003), wherein each isolate was evaluated using the following 4 variables. Mycelial growth rate was assessed by transferring 6-mm-diameter PDA medium discs derived from 7-day-old colonies into other PDA medium plates, including 4 replicates for each isolate, and assessing colony growth daily until the 7th day of incubation by averaging the colony's diameter in diametrically opposite directions. Sporulation was evaluated at day 10 of incubation by adding $20 \mathrm{~mL}$ sterile distilled water to each plate used for evaluating mycelial growth, scraping the colonies and sieving through a double layer of gauze to estimate the conidial concentration (conidia $/ \mathrm{mL}$ ) using a Neubauer chamber. Colony pigmentation was based on observation and the colony and aerial mycelium pigmentation was recorded. The colors were defined as described by Nelson et al. (1983). Conidial length and width were assessed from a sample from a 2-mL fungal conidia suspension in sterile distilled water, which was pipetted onto a microscope slide. Conidia were measured using a light microscope with a micrometer at $40 \mathrm{X}$ magnification. Thirty conidia were measured for each isolate. Isolates were also transferred onto CLA media (Nelson et al., 1983) to detect the presence of chlamydospores (Leslie and Summerell, 2006) in case they were present but had not been observed on the PDA media. 


\section{Molecular characterization}

This procedure was also conducted using only the 11 pathogenic Fusarium spp isolates. Pathogen DNA extraction was performed according to the cetyltrimethylammonium bromide method described by Doyle and Doyle (1990). Extracted genomic DNA samples were analyzed by polymerase chain reaction (PCR) to amplify the TEF-1 $\alpha$ region using the EF1-T (ATGGGTAAGGARGACAAGAC) and EF1-1567R (ACHGTRCCRATACCACCRATCTT) primers (Rehner and Buckley, 2005).

The reaction contained approximately $30 \mathrm{ng}$ DNA, $10 \mathrm{X}$ buffer, $2.5 \mu \mathrm{M}$ each dNTP, 20 $\mathrm{nM} \mathrm{MgCl}, 25$ pmol each primer, and $5 \mathrm{U}$ Taq polymerase enzyme; the reaction mixture was brought to volume using ultrapure water. Reactions were performed in an MJ Research, Inc. PTC - 100 MT thermocycler (Quebec, Canada) under the following thermal conditions: $94^{\circ} \mathrm{C}$ for $2 \mathrm{~min} ; 30$ cycles at $94^{\circ} \mathrm{C}$ for $45 \mathrm{~s}, 55^{\circ} \mathrm{C}$ for $30 \mathrm{~s}$, and $72^{\circ} \mathrm{C}$ for $35 \mathrm{~s}$; and $72^{\circ} \mathrm{C}$ for $10 \mathrm{~min}$. PCR products were stored at $4^{\circ} \mathrm{C}$ upon completion of the reaction. A negative control without DNA was included in the PCR amplifications. Amplified fragments and controls were separated by $1.2 \%$ agarose gel electrophoresis in $1 \mathrm{X}$ TBE buffer (10.8 g Tris base, $5.5 \mathrm{~g}$ boric acid, $4 \mathrm{~mL} 0.5 \mathrm{M}$ ethylenediaminetetraacetic acid, and $4 \mathrm{~mL}$ distilled water) containing ethidium bromide and bands were visualized under ultraviolet light.

The PCR products were purified using 13\% PEG 8000 and the sequences generated were 900-1200 base pairs. Sequencing was performed on a Mega BACE 500 Sequencer (Amersham Biosciences; Amersham, UK). Sequenced fragments were analyzed using the BioEdit software (Hall, 1999). Nucleotide sequences were compared with those previously deposited in GenBank regarding the pathogens isolated. The GenBank sequences with the highest scores (more than $98 \%$ of similarity and coverage) were selected and aligned with sequences determined by sequencing using the ClustalW algorithm, and phylogenetic analysis was conducted using the neighbor-joining statistical method with 1000 replicates on the MEGA software version 4 (Tamura et al., 2007). The model was selected using the FindModel software, which establishes the best model based on a file with the sequences chosen aligned using BioEdit (Hall, 1999). The similarity of nucleotide sequences between isolates was calculated using the BLAST procedure (http://blast.ncbi.nlm.nih.gov). All isolate sequences were submitted to GenBank and the accession codes are shown on the dendrograms.

\section{Data analysis}

Quantitative data regarding morphological characterization were submitted to a multivariate analysis technique for cluster analysis of the isolates. These analyses were performed using the GENES software (version 2009.7.0). The array of standardized Euclidean distances (D2) was calculated as a dissimilarity measure and used to cluster the isolates according to the unweighted pair group method with arithmetic mean (UPGMA) method (Cruz, 2008).

The sequence obtained for each isolate was aligned with the sequences available in the database using BLAST, and the sequences with the highest coverage (higher than 98\%) and degree of similarity (higher than 98\%) were selected for each isolate. Subsequently, sequences chosen using the software were aligned with isolate sequences using the BioEdit software (Hall, 1999). 


\section{RESULTS}

The Fusarium spp isolates $\mathrm{F}_{1}, \mathrm{~F}_{3}, \mathrm{~F}_{5}, \mathrm{~F}_{6}, \mathrm{~F}_{7}, \mathrm{~F}_{8}, \mathrm{~F}_{9}, \mathrm{~F}_{11}, \mathrm{~F}_{17}, \mathrm{~F}_{19}$, and $\mathrm{F}_{20}$ were pathogenic to pecan seedlings, causing the following symptoms: choke disease $\left(\mathrm{F}_{1}, \mathrm{~F}_{3}, \mathrm{~F}_{5}, \mathrm{~F}_{7}, \mathrm{~F}_{8}, \mathrm{~F}_{9}\right.$, and $\mathrm{F}_{17}$ isolates), leaf necrosis associated with root $\operatorname{rot}\left(\mathrm{F}_{1}, \mathrm{~F}_{6}, \mathrm{~F}_{7} \mathrm{~F}_{9}, \mathrm{~F}_{11}, \mathrm{~F}_{19}\right.$, and $\mathrm{F}_{20}$ isolates), shoot wilt associated with root $\operatorname{rot}\left(\mathrm{F}_{1}, \mathrm{~F}_{3}, \mathrm{~F}_{5}, \mathrm{~F}_{7}, \mathrm{~F}_{8}, \mathrm{~F}_{9}\right.$, and $\mathrm{F}_{17}$ isolates), and even plant death, which was diagnosed upon inoculation with $\mathrm{F}_{11}$. Some isolates also produced pre-emergence damping-off $\left(\mathrm{F}_{7}\right.$ and $\left.\mathrm{F}_{9}\right)$. Symptoms appeared approximately 60 days after emergence (Figure 1). Isolates $\mathrm{F}_{14}, \mathrm{~F}_{15}, \mathrm{~F}_{21}$, and $\mathrm{F}_{23}$ produced no symptoms in seedlings and were therefore considered to be non-pathogenic.

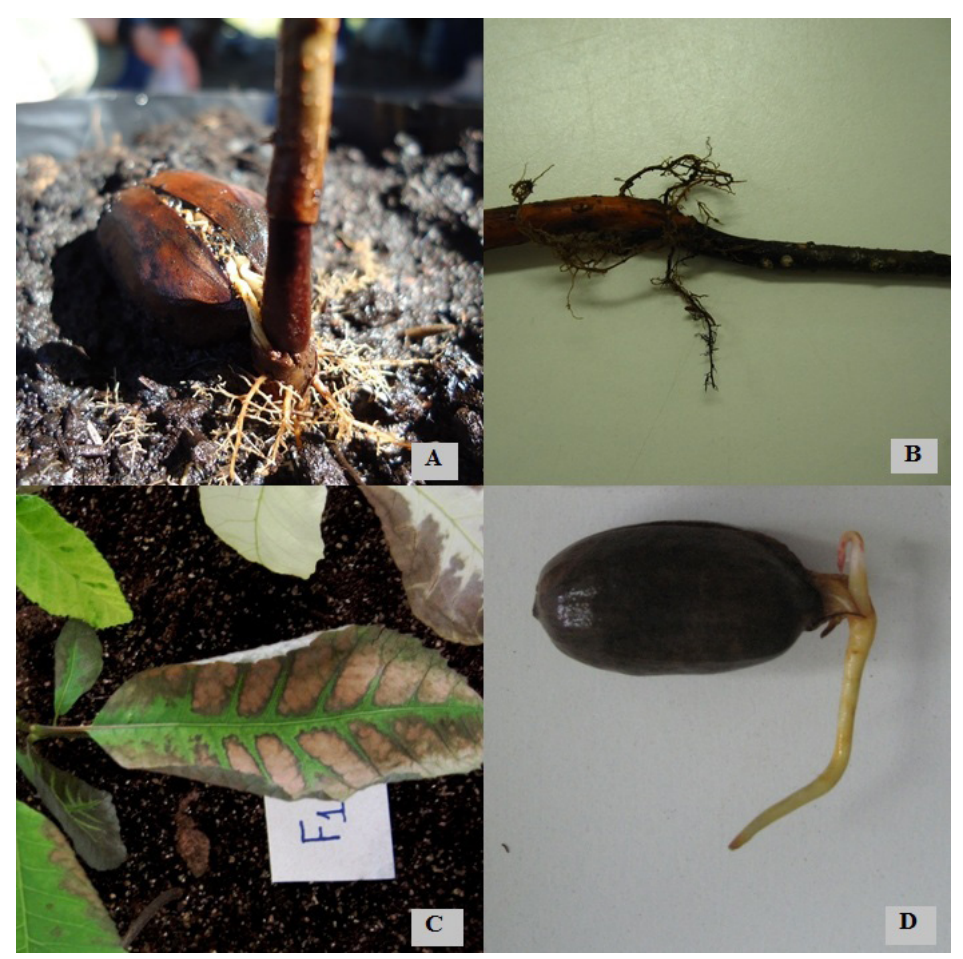

Figure 1. Symptoms obtained by inoculation of Fusarium spp on Carya illinoinensis. Choke disease (A); root rot (B); leaf necrosis associated with root rot (C); damping-off (D).

Regarding the daily mycelial growth rate (MGR), $\mathrm{F}_{3}, \mathrm{~F}_{19}$, and $\mathrm{F}_{20}$ were the fastestgrowing isolates and reached confluence within the plate's maximum diameter $(90 \mathrm{~mm})$ within 7 days, whereas isolate $\mathrm{F}_{17}$ exhibited the lowest MGR (Table 2). Some isolates appeared to cluster when taking into account their MGRs; these isolates included $\mathrm{F}_{8}, \mathrm{~F}_{9}$, and $\mathrm{F}_{11}$, which exhibited very close MGR values, as well as $\mathrm{F}_{1}, \mathrm{~F}_{5}$, and $\mathrm{F}_{7}$. These results indicate the usefulness of this variable for differentiating and grouping the isolates. Regarding colony pigmentation, 5 different combinations of colony pigmentation and 4 different combinations of aerial mycelium color were observed, thus effectively differentiating colony characteristics because these colors are easily visualized. 


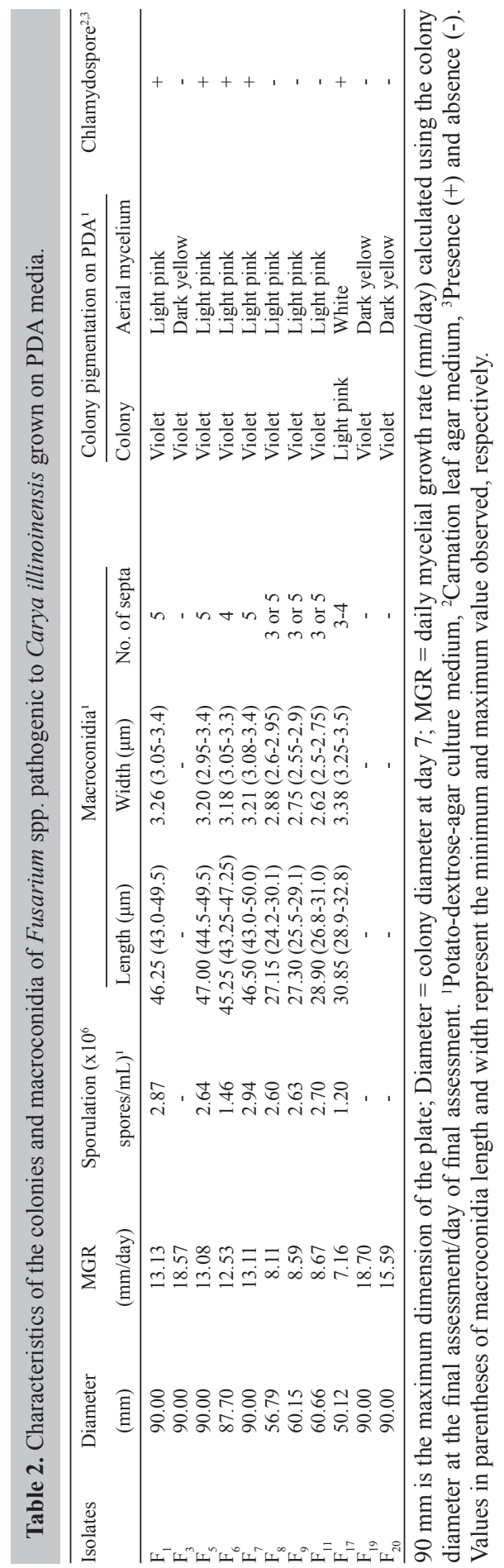


Sporulation ranged from $1.20 \times 10^{6}\left(\mathrm{~F}_{17}\right)$ to $2.94 \times 10^{6}$ spores $/ \mathrm{mL}\left(\mathrm{F}_{7}\right)$, the dimensions of macroconidia ranged in length from $27.13\left(\mathrm{~F}_{8}\right)$ to $47.0 \mu \mathrm{m}\left(\mathrm{F}_{5}\right)$ and in width from $2.62\left(\mathrm{~F}_{11}\right)$ to $3.38 \mu \mathrm{m}\left(\mathrm{F}_{17}\right)$, and the number of septa ranged from 3 to 5 (Table 2). The $\mathrm{F}_{3}, \mathrm{~F}_{19}$, and $\mathrm{F}_{20}$ isolates exhibited no sporulation (macroconidia) on the media tested, which is a key characteristic used for grouping isolates. The formation of chlamydospores, noted in isolates $\mathrm{F}_{1}, \mathrm{~F}_{5}$, $\mathrm{F}_{6}, \mathrm{~F}_{7}$, and $\mathrm{F}_{17}$, is common in some species of Fusarium, including Fusarium chlamydosporum Wollenweber \& Reinking and Fusarium oxysporum Schlechtendahl emend. Snyder \& Hansen (Gerlach and Nirenberg, 1982).

We established whether differences in morphological characteristics (colony diameter, sporulation, macroconidial width, and length) represented valid characters for grouping isolates by using the dendrogram generated via the UPGMA clustering method (Figure 2A). The formation of 3 clusters was noted: the first was formed by isolates $\mathrm{F}_{1}, \mathrm{~F}_{7}, \mathrm{~F}_{5}$, and $\mathrm{F}_{6}$; the second was formed by $\mathrm{F}_{9}, \mathrm{~F}_{11}$, and $\mathrm{F}_{8}$; and the third was formed by $\mathrm{F}_{17}$ alone. Isolates $\mathrm{F}_{3}, \mathrm{~F}_{19}$, and $\mathrm{F}_{20}$ were not included in this dendrogram because they exhibited no sporulation and only the colony diameter parameter was available for assessment. The lowest dissimilarities were observed between isolates $\mathrm{F}_{1}$ and $\mathrm{F}_{7}$, followed by $\mathrm{F}_{9}$ and $\mathrm{F}_{11}$, and clustering between these pairs of isolates showed dissimilarities below $10 \%$.
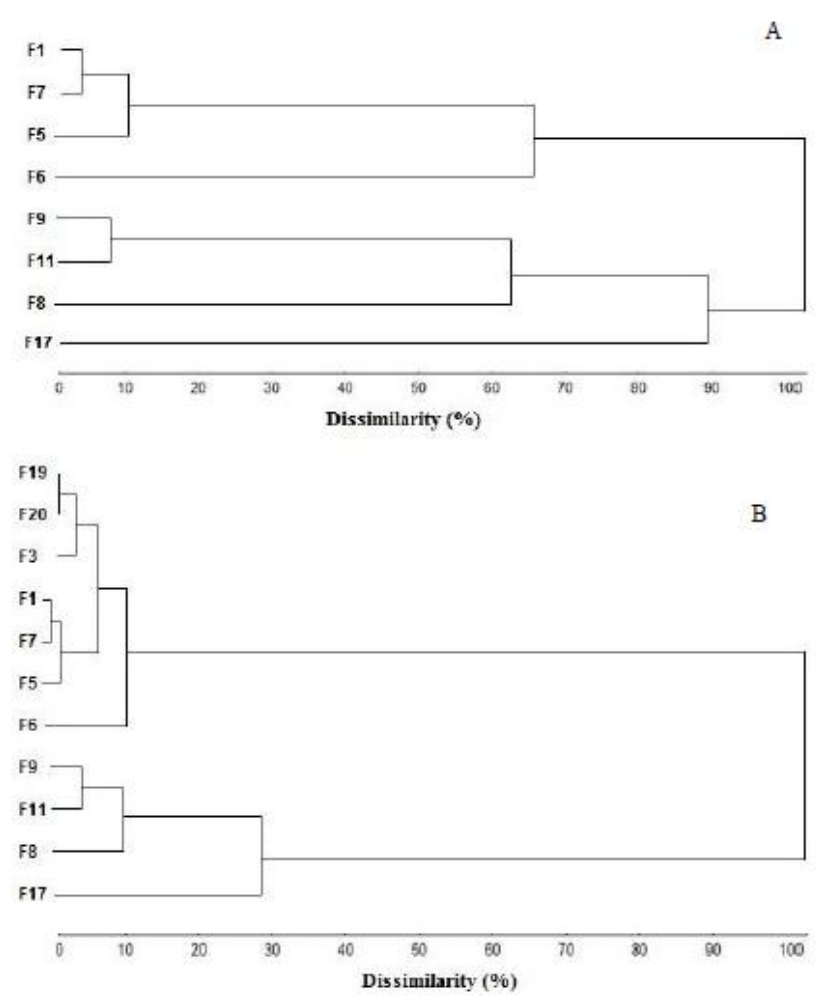

Figure 2. Dendrogram showing the percentage of dissimilarity between Fusarium spp isolates pathogenic to Carya illinoinensis. The dendrogram was designed using the unweighted pair group with arithmetic mean method based on a Euclidean distance matrix analysis using the 4 morphological characteristics evaluated: colony diameter, sporulation, and conidial length and width (A) as well as using only colony diameter (B). 
Clustering analysis was performed using only the colony diameter variable to include isolates that did not exhibit sporulation $\left(\mathrm{F}_{3}, \mathrm{~F}_{19}\right.$, and $\left.\mathrm{F}_{20}\right)$, as shown in Figure 2B. Based on colony diameter, the isolates included were grouped on the same branch with a dissimilarity below $10 \% . \mathrm{F}_{19}$ and $\mathrm{F}_{20}$ were considered to be identical because the dissimilarity was null. Multivariate analysis related to Figure 2A also provided the relative contributions of each of the characteristics to divergence; conidial width was responsible for $99.98 \%$ of divergence. This result indicates that the differentiation of the Fusarium spp isolates into groups formed in the dendrogram was due nearly entirely to the conidial width characteristic.

Figure 3 shows the phylogenetic dendrogram constructed based on the TEF-1 $\alpha$ sequences, which should be more confinable for identification of Fusarium species or species complex compared to other gene regions. The $\mathrm{F}_{17}$ isolate was in the first branch of the dendrogram grouped with the F. oxysporum sequences. This isolate also showed greater dissimilarity from other isolates when morphological characteristics were used for clustering (Figure 2A and $\mathrm{B}$ ). Therefore, molecular identification confirmed that $\mathrm{F}_{17}$ was different at the species level from the other isolates.

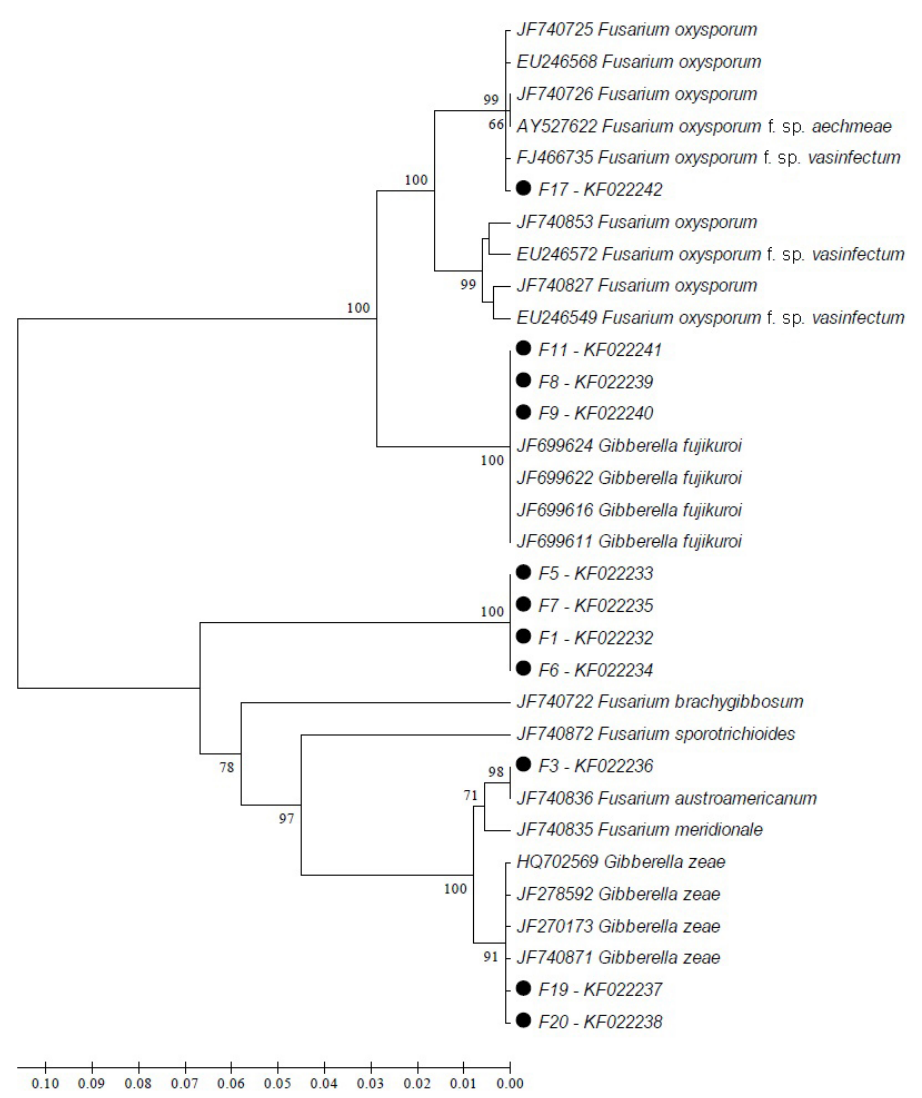

Figure 3. Phylogenetic dendrogram of the Fusarium spp isolates that were pathogenic to Carya illinoinensis, derived from sequences of the TEF-1 $\alpha$ gene according to the neighbor-joining statistical method and based on 1000 bootstrap replicates. Evolutionary distances were calculated using the Jukes-Cantor model. The numbers associated with the branches represent the bootstrap numbers. 
The $\mathrm{F}_{8}, \mathrm{~F}_{9}$, and $\mathrm{F}_{11}$ isolates appeared in the second branch of the dendrogram grouped with the Gibberella fujikuroi (Sawada) Ito in Ito \& K. Kimura (anamorph: F. fujikuroi Nirenberg) sequences, known as the G. fujikuroi species complex, to which Fusarium proliferatum also belongs (Gerlach and Nirenberg, 1982) (Figure 3). $\mathrm{F}_{1}, \mathrm{~F}_{5}, \mathrm{~F}_{6}$, and $\mathrm{F}_{7}$ were again clustered in the same clade, as occurred with clusters based on morphological characteristics, in combination with sequences of F. brachygibbosum Padwick and Fusarium sporotrichioides Sherbakoff, which belong to the same species complex as F. chlamydosporum. Thus, for these 4 isolates, identification was achieved at the species complex level. The lack of other accessions of the F. chlamydosporum species in the dendrogram resulted from the limited number of sequences deposited in GenBank for this region and for other species of Fusarium.

Finally, $\mathrm{F}_{19}$ and $\mathrm{F}_{20}$ were grouped with sequences of Gibberella zeae. These isolates $\left(\mathrm{F}_{19}\right.$ and $\left.\mathrm{F}_{20}\right)$ were closer to one another, indicating greater genetic proximity, which can be explained by their origin of collection. In contrast, $\mathrm{F}_{3}$ was grouped into the same branch as Fusarium austroamericanum T. Aoki, Kistler, Geiser \& O'Donnell when using the TEF-1 $\alpha$ region. Isolate $\mathrm{F}_{3}$ is likely $F$. austroamericanum, but sequence data from another informative locus would be desirable for a definitive identification. Therefore, sequencing of the TEF-1 $\alpha$ region raised doubts regarding the identification of $\mathrm{F}_{3}$ at the species level, supporting that this isolate belongs to the $F$. graminearum species complex.

\section{DISCUSSION}

Angelotti et al. (2006) performed morphological characterization of $F$. graminearum isolates associated with Fusarium head blight of wheat and triticale in the southern region of Brazil using some of the characteristics that were used in this study, including culture pigmentation on PDA medium, the dimensions of macroconidia on CLA medium, the number of macroconidial septa, and the presence of chlamydospores. The authors used these characteristics and molecular techniques as well as PCR, and they identified 20 of the isolates collected as $F$. graminearum. In taxonomic keys, including those developed by Gerlach and Nirenberg (1982) and Nelson et al. (1983), these same characteristics were used to identify Fusarium species. Leslie and Summerell (2006) highlighted some species of Fusarium that rarely produce macroconidia, including one species, F. musarum Logrieco \& Marasas, in which macroconidia are entirely absent, which may be an important characteristic of cluster isolates. Kristensen et al. (2005) suggested that phylogenetic analyses of Fusarium spp should be developed based on isolates that are well-characterized morphologically and, preferably, accompanied by specific descriptions, including host, geographic origin, secondary metabolites produced, and pathogenicity. Leslie and Summerell (2006) advocate the use of the morphological basis of Fusarium spp but recognize the limitations of this approach and the need for improvement and changes.

Rahjoo et al. (2008) used various morphophysiological characteristics to identify 191 isolates of Fusarium spp, including the morphology of colonies grown on PDA and the morphology of macroconidia, microconida, conidiogenous cells, and chlamydospores evaluated using cultures grown on Synthetischer Nährstoffarmer Agar and CLA media. The species of 187 isolates were identified using only morphology; however, in the study above, the authors confirmed their identification by sequencing the $T E F-1 \alpha$ gene. Again, the importance of combining morphological and genetic characters for fungal identification was highlighted.

Regarding clustering by morphological characters, Michereff et al. (2003) also used the UPGMA method based on a Euclidean distance matrix analysis to assess the variability of 
38 Alternaria brassicicola (Schwein.) Wiltshire isolates, using epidemiological (incubation period, severity, rate of disease progression, and area under the disease progression curve) and physiological (mycelial growth rate, sporulation, and conidial germination) variables in addition to sensitivity to the iprodione fungicide in clustering analysis. Teixeira et al. (2004) used the same technique to group and differentiate 10 Acremonium strictum W. Gams isolates obtained from maize seeds (Zea mays L.) with relative genetic distances assessed using 9 morphophysiological markers.

Recently, studies involving the identification of fungal isolates have attempted to combine identification by morphological and molecular characteristics. Andrade et al. (2007) conducted a study aimed at characterizing the morphological, cultural, and pathogenic variability of Colletotrichum gloeosporioides (Penz.) Penz. \& Sacc. samples isolated from the papaya tree (Carica papaya). Subsequently, the isolates were molecularly identified by PCR using taxon-specific primers and PCR-restriction fragment length polymorphism analysis of the ITS region, combining morphological and molecular techniques.

The combination of sequencing results from different regions or different genes provides more reliable fungal species identification. As observed in the present study, species complexes that were morphologically differentiated were confirmed by $T E F-1 \alpha$ sequencing.

Therefore, isolates that are pathogenic to the pecan tree were identified as belonging to the $F$. chlamydosporum species complex, F. graminearum species complex, F. proliferatum, and $F$. oxysporum. These pathogen species have not been previously reported for pecan trees in Brazil. Fusarium chlamydosporum can be considered to be a saprophyte (Gerlach and Nirenberg, 1982), although Nahar and Mushtaq (2006) found that F. chlamydosporum is associated with sunflower seeds and detected its pathogenicity causing symptoms of wilt and collar rot.

Members of the F. graminearum complex can infect wheat (Triticum aestivum L.), barley (Hordeum vulgare L.), maize (Zea mays L.), and other cereals worldwide, causing the Fusarium head blight (Boutigny et al., 2011). Pathogen-infected grains also show contamination with mycotoxins from the group of trichothecenes, including deoxynivalenol and nivalenol (Astolfi et al., 2011). This species complex is very important for the pecan tree, but also may be a source of fungal spread to most other crops grown in the study region, such as rice and cereals.

The $F$. proliferatum species complex members are pathogenic to several crops, are highly toxicogenic, and can produce mycotoxins, including fumonisins, fusaric acid, beauvericin, fusaproliferin, and moniliformin, according to Bottalico (1998). Finally, F. oxysporum has been observed worldwide given its intense attacks on several crops, including bananas, tomatoes, beans, potatoes, sugar cane, and passion fruit. This species has been detected in forest species by Krugner et al. (1970), who correlated the symptoms of wilting and apical drying in seedlings of Pinus elliottii var. elliottii, and in Pinus taeda (Grigoletti and Auer, 2006).

Therefore, the morphological characteristics of pathogenic isolates of Fusarium spp, particularly conidial width, were important for separating and clustering in this study, indicating the potential differences and similarities at the genetic level, which were confirmed by sequencing the $T E F-1 \alpha$ region. Sequencing of the region used in this study provided key data with greater reliability for species complex identification and increased the information regarding this species.

In this study, we identified species groups of Fusarium in Brazil that are pathogenic to the pecan tree under controlled conditions. 


\section{ACKNOWLEDGMENTS}

The authors thank Coordenação de Aperfeiçoamento de Pessoal de Nível Superior, CAPES for granting the doctoral scholarship to the first author.

\section{REFERENCES}

Alfenas AC and Mafia RG (2007). Métodos em Fitopatologia. Universidade Federal de Viçosa, Viçosa.

Andrade EM, Uesugi CH, Ueno B, Ferreira B, et al. (2007). Caracterização morfocultural e molecular de isolados de Colletotrichum gloeosporioides patogênicos ao mamoeiro. Fitopatol. Bras. 32: 21-31.

Angelotti F, Tessmann DJ, Alves TCA, Vida JB, et al. (2006). Caracterização morfológica e identificação molecular de isolados de Fusarium graminearum associados à giberela do trigo e triticale no sul do Brasil. Summa Phytopathol. 32: $177-179$.

Astolfi P, dos Santos J, Schneider L, Gomes LB, et al. (2011). Molecular survey of trichothecene genotypes of Fusarium graminearum species complex from barley in southern Brazil. Int. J. Food Microbiol. 148: 197-201.

Bottalico A (1998). Fusarium diseases of cereals: species complex and related mycotoxin profiles in Europe. J. Plant Pathol. 80: 85-103.

Boutigny AL, Ward TJ, Van Coller GJ, Flett B, et al. (2011). Analysis of the Fusarium graminearum species complex from wheat, barley and maize in South Africa provides evidence of species-specific differences in host preference. Fungal. Genet. Biol. 48: 914-920.

Cruz C.D. (2008). Programa Genes: Diversidade Genética. Universidade Federal de Viçosa, Viçosa.

Doyle JJ and Doyle JL (1990). Isolation of Plant DNA from Fresh Tissue. Focus 12: 13-15.

Gerlach W and Nirenberg H (1982). The Genus Fusarium - A Pictorial Atlas. Biologische Bundesanstald für Landund. Institut für Mikrobiologie, Dahlem, Berlin.

Grigoletti A Jr and Auer CG (2006). Fusariose em Mudas de Pinus taeda. Embrapa Florestas, Colombo (Comunicado técnico, 166).

Hall TA (1999). BioEdit: a user-friendly biological sequence alignment editor and analysis program for Windows 95/98/ NT. 41: 95-98. Nucleic Acids Symp. Series 41: 95-98.

Klingelfuss LH, Yorinori JT and Destro D (2007). Métodos de inoculação para quantificação de resistência em soja a Fusarium solani f. sp. glycines, em casa-de-vegetação. Fitopatol. Bras. 32: 50-55.

Kristensen R, Torp M, Kosiak B and Holst-Jensen A (2005). Phylogeny and toxigenic potential is correlated in Fusarium species as revealed by partial translation elongation factor 1 alpha gene sequences. Mycol. Res. 109: 173-186.

Krugner T L, Carvalho PGT and Galli F (1970). Nota prévia sobre a ocorrência de Fusarium sp. em Pinus elliottii Engelm. O Solo 62: 45-48.

Leslie J and Summerell BA (2006). The Fusarium Laboratory Manual. Blackwell Publishing, Hoboken.

Marchiori JNC (1997). Dendrologia das Angiospermas: das Magnoliáceas às Flacourtiáceas. Editora da Universidade Federal de Santa Maria, Santa Maria.

Michereff SJ, Noronha MA, Rocha OM Jr, Silva JA, et al. (2003). Variabilidade de isolados de Alternaria brassicicola no estado de Pernambuco. Fitopatol. Bras. 28: 656-663.

Nahar S and Mushtaq M (2006). Pathogenecity and transmission studies of seedborne Fusarium species (sec. Liseola and Sporotrichiella) in sunflower. Pakistan J. Bot. 38.

Nelson PE, Tousson TA and Marasas WFO (1983). Fusarium Species: An Illustrated Manual for Identification. Pennsylvania State University Press, Philadelphia.

O’Donnell K, Kistler HC, Cigelnik E and Ploetz RC (1998). Multiple evolutionary origins of the fungus causing Panama disease of banana: concordant evidence from nuclear and mitochondrial gene genealogies. Proc Natl. Acad. Sci. U. S. A. 95: 2044-2049.

Ortiz ERN and Camargo LEA (2005). Doenças da Nogueira Pecan. In: Manual de Fitopatologia: Doenças das Plantas Cultivadas. 4th edn. (Kimati, H. et al. Eds.) Agronômica Ceres, São Paulo, 501-505.

Rahjoo V, Zad J, Javan-Nikkhah M, Mirzadi Gohari A, et al. (2008). Morphological and molecular identification of Fusarium isolated from maize ears in Iran. J. Plant. Pathol. 90: 463-468.

Rehner SA and Buckley E (2005). A Beauveria phylogeny inferred from nuclear ITS and EF1-alpha sequences: evidence for cryptic diversification and links to Cordyceps teleomorphs. Mycologia 97: 84-98.

Tamura K, Dudley J, Nei M and Kumar S (2007). MEGA4: Molecular Evolutionary Genetics Analysis (MEGA) software version 4.0. Mol. Biol. Evol. 24: 1596-1599. 
Taylor JW, Jacobson DJ, Kroken S, Kasuga T, et al. (2000). Phylogenetic species recognition and species concepts in fungi. Fungal. Genet. Biol. 31: 21-32.

Teixeira H, Vieira MGGC and Machado JC (2004). Marcadores morfofisiológicos e isoenzimáticos na análise da diversidade genética de isolados de Acremonium strictum. Fitopatol. Bras. 29: 413-418.

Waalwijk C, Koning JRA and Baayen RP (1996). Discordant groupings of Fusarium spp. from sections Elegans, Liseola and Dlaminia based on ribosomal ITS1 and ITS2 sequences. Mycologia 88: 361-368. 